\title{
IMPEACHMENT AS CONGRESSIONAL CONSTITUTIONAL INTERPRETATION
}

\author{
NEAL KUMAR KATYAL*
}

\section{INTRODUCTION}

In the past year, America experienced an intense constitutional debate waged in its newspapers, kitchens, and internet chat rooms. This debate was remarkable, and not only because a constitutional issue-the meaning of "high crimes and misdemeanors"-managed to capture the attention of the public. It was also striking because the constitutional argument took place outside of the one institution that many understand to be the primary interpreter of the Constitution, the Supreme Court. ${ }^{1}$ For a textualist, this omission should not be surprising, as the Constitution vests the judiciary with virtually no function in impeachment. Yet the removal of the judiciary from impeachment highlights the ways in which our legislature is called upon to make interpretive constitutional decisions.

During the interpretive debate over whether to impeach President Clinton, Democrats in Congress accused their Republican colleagues of being inconsistent in their approach to constitutional interpretation (and vice-versa). The Democrats argued that "high crimes and misdemeanors" had a very narrow meaning at the founding of the Constitution, and the Republicans responded by arguing that they should not be hemmed in by a two-century-old interpretation of a living document. Consider, as one example, what Representative Maxine Waters said during the impeachment debate:

I am absolutely amazed at the liberal and loose interpretation of the Constitution that I'm hearing from conservatives. Usually, progressives are accused of loose interpretation and usually conservatives are considered to have strict interpretation of the constitution and law. But sitting in this committee, I have witnessed the most-the loosest interpretation of the Constitution, as my colleagues on the other side of the aisle have dealt with the meaning of high crimes and misdemeanors. ${ }^{2}$

The party of originalism had thrown in the towel, and all for political points to boot.

Copyright (C) 2000 by Neal Kumar Katyal

This essay is also available at http://www.law.duke.edu/journals/63LCPKatyal.

* Associate Professor of Law, Georgetown University Law Center.

1. Powell v. McCormack, 395 U.S. 486, 549 (1969) (stating that the Supreme Court is "the ultimate interpreter of the Constitution"); see also Cooper v. Aaron, 358 U.S. 1, 18 (1958) (declaring that the "federal judiciary is supreme in the exposition of the law of the Constitution"). 857390 .

2. House of Representatives, Debate on Impeachment, Dec. 12, 1998, reprinted in 1998 WL 
This essay contends that this attack on the Republicans was wrong. In defending the Republicans, I am not interested in their political motivations (if any) but rather the jurisprudential issues that their position raised. I argue that one can adhere to originalism in the context of judicial interpretation and, nevertheless, believe in a broader style of interpretation for the legislature. Originalism, as practiced in this way, is a doctrine that constrains unelected judges from an unduly free interpretive approach, but it does not preclude Congress from making constitutional judgments that are more flexible and nuanced.

At stake in this project is something larger than the debate over originalism. Constitutionalists have assumed, too quickly in my view, that symmetry should exist between the interpretive styles of the courts and Congress. This assumption, which I shall call the myth of interpretive symmetry, slights the many reasons why an interpretive method may work well in one area and not work as well in another. Instead of mapping out all these possible divergences, I illustrate the point with three examples: the roles of history, precedent, and moral philosophy. I show how, in each instance, arguments can be made to suggest that divergent institutional roles should be taken into account in formulating a comprehensive interpretive philosophy about the Constitution.

This essay largely concentrates on the first example, the role of history. It contrasts two prevailing theories of constitutional law, legal process and minority protection, and argues that implicit in each theory is an account of why the role of history might differ depending on whether the decisionmaker is the judiciary or Congress. It is well established at this point that the ultimate purposes of the Constitution will influence what style of interpretation is appropriate. What this essay seeks to show is that those purposes counsel different interpretive theories for different constitutional actors. This essay does not address the debate on whether Congress should interpret the Constitution, or which branch has the ultimate authority to act as its interpreter. After all, the Constitution's structure dictates that courts will not be the only branch to interpret the Constitution. But the Constitution does not tell us how much interpretive power any branch should have, nor does it tell us how Congress should interpret the document. $^{3}$ My goal is to demonstrate that the myth of interpretive symmetry has obscured what may be a rich variety of ways to read the Constitution with respect to different branches of government.

In each of the three sections of the analysis, the essay discusses a particular constitutional methodology and highlights its central features. It then discusses whether the arguments for and against that methodology apply with equal force

3. See U.S. CONST. art. VI, $\S 3$ (Oath Clause); id. art. II, $\S 4$ (conviction upon impeachment for "high crimes and misdemeanors"); see also Senator Sam Ervin, as quoted in PETER SCHUCK, THE JUDICIARY COMMITTEES 175 (1975) ("Every Congressman is bound by his oath to support the Constitution, and to determine to the best of his ability whether proposed legislation is constitutional when he casts his vote in respect to it.”); 30 ANNALS OF CONG. 577 (1817) (statement of Sen. John C. Calhoun) ("The Constitution is my letter of instruction. Written by the hand of the people, stamped with their authority, it admits of no doubt as to its obligation. ... This is the solemn voice of the people, to which I bow in perfect submission. It is here the vox populi is the vox Dei."). 
to legislative and judicial interpretation. Because of limitations of space and time, the essay focuses on interpretive symmetry as applied to impeachment, and not other constitutional decisions Congress is asked to make. It is important to note at the outset that there are some features that distinguish impeachment from these other decisions. For one thing, the Constitution essentially removes the courts from the impeachment process. ${ }^{4}$ For another, the supermajority voting rule in the Senate, which requires a two-thirds vote to convict, may imply that different constitutional standards should be at work. ${ }^{5}$ This essay does not so much seek to resolve these interpretive questions in constitutional areas outside of impeachment as simply to pose them. It will not get into the hard questions of how the Senate should use its "Advice and Consent" power, or the methodology it should use when deciding whether a particular piece of legislation is constitutional. All of this is extremely important, but requires more attention than can be given in this symposium. ${ }^{6}$

\section{II}

\section{THE ROLE OF HISTORY}

The question of what methodological tools Congress should use in interpreting the Constitution has largely gone unasked for the past 200 years. However in 1791, James Madison, then a House Representative, laid down the following rules to guide his interpretation in assessing the constitutionality of the proposed Bank of the United States: be just.

An interpretation that destroys the very characteristic of the Government cannot

Where the meaning is clear, the consequences, whatever they may be, are to be admitted-where doubtful, it is fairly triable by its consequences.

In controverted cases, the meaning of the parties to the instrument, if to be collected by reasonable evidence, is a proper guide.

Contemporary and concurrent expositions are a reasonable evidence of the meaning of the parties.

In this speech, Madison does not pick one methodology or the other. Instead, he expresses a preference for historical interpretation, but admits that in questionable cases, the "consequences" of a particular interpretation may be consid-

4. See Nixon v. United States, 506 U.S. 224, 233 (1993) ("The history and contemporary understanding of the impeachment provisions support our reading of the constitutional language. The parties do not offer evidence of a single word in the history of the Constitutional Convention or in contemporary commentary that even alludes to the possibility of judicial review in the context of the impeachment powers.").

5. Hamilton explained that "[a]s the concurrence of two-thirds of the senate will be requisite to a condemnation, the security to innocence, from this additional circumstance, will be as complete as itself can desire." THE FEDERALIST No. 66, at 446 (Jacob E. Cooke ed., 1961).

6. For further discussion of these issues, see Neal Kumar Katyal, Legislative Constitutional Interpretation, _ DUKE L.J__ (forthcoming 2001).

7. 2 Gales \& SeAton's Debates and Proceedings of The Congress of the United STATES 1944, 1946 (1834) (statement of James Madison). 
ered as well. Nevertheless, Madison's speech serves as a helpful starting point in framing the question of what interpretive methodology Congress should use in interpreting the Constitution. The years since the founding of the Constitution have brought an abundance of different methodological proposals for courts to consider in evaluating historical claims. This essay focuses primarily on the Legal Process and Protection-of-Minorities Schools.

\section{A. The Legal Process School}

A prevalent school of constitutional thought holds that the Constitution is designed to enhance majoritarian functioning and democratic self-rule. ${ }^{8}$ The Constitution, under this philosophy, is not as much focused upon protecting minority interests as it is focused upon protecting those of the majority. Within this tradition, there are those who believe that judges, when reading the Constitution, should be guided by the original intent of the Framers. This intent is divined, it is said, through close historical analysis of the Constitution. By hewing to such constitutional history, judges act with fidelity to majority interests and avoid imposing their personal judgments when they interpret vague textual provisions. For example, according to this view, Roe v. Wade, because it went beyond the historical contours of the right to privacy, was an instance of judicial activism that usurped the proper role of the legislature. ${ }^{9}$

Without the anchor of history, the theory goes, judges will seek to impose their own values on the Constitution, creating indeterminacy of interpretation and a countermajoritarian difficulty. As Justice Scalia has written,

[t]he ascendant school of constitutional interpretation affirms the existence of what is called The Living Constitution, a body of law that (unlike normal statutes) grows and changes from age to age, in order to meet the needs of a changing society. And it is the judges who determine those needs and "find" that changing law. Seems familiar, doesn't it? Yes, it is the common law returned, but infinitely more powerful than what the old common law ever pretended to be, for now it trumps even the statutes of democratic legislatures. ${ }^{10}$

Or, as Judge Bork states at the outset of his book:

8. See Henry M. Hart, Jr. \& Albert M. Sacks, The Legal Process (William N. Eskridge \& Phillip P. Frickey eds., 1994).

9. See Planned Parenthood v. Casey, 505 U.S. 833, 944, 952 (1992) (Rehnquist, C.J., dissenting) ("We believe that Roe was wrongly decided.... Nor do the historical traditions of the American people support the view that the right to terminate one's pregnancy is 'fundamental.' ... [I]t can scarcely be said that any deeply rooted tradition of relatively unrestricted abortion in our history supported the classification of the right to abortion as 'fundamental' under the Due Process Clause of the Fourteenth Amendment. We think, therefore, both in view of this history and of our decided cases dealing with substantive liberty under the Due Process Clause, that the Court was mistaken in Roe when it classified a woman's decision to terminate her pregnancy as a 'fundamental right' that could be abridged only in a manner which withstood "strict scrutiny."); see also Michael H. v. Gerald D., 491 U.S. 110, 127 n.6 (1989).

10. ANTONin ScAlia, A MATter of INTERPRETAtion 38 (1997). Justice Scalia rejects, it should be noted, the original intent of the Framers as a guidepost to constitutional interpretation. Id. Instead, he prefers a methodology that focuses on the text, $i d$. at 37 , as well as historical analysis of the original understanding of the text, $i d$. at 38 ("What I look for in the Constitution is ... the original meaning of the text."). See also id. at 133. 
[T]he Constitution is the trump card in American politics, and judges decide what the Constitution means. When the Supreme Court invokes the Constitution, whether legitimately or not, as to that issue the democratic process is at an end.... The intended function of the federal courts is to apply the law as it comes to them from the hands of others. ... [A judge] is bound by the only thing that can be called law, the principles of the text, whether Constitution or statute, as generally understood at the enactment. ${ }^{11}$

Are adherents to this philosophy compelled to espouse it in the legislative context? ${ }^{12}$ More specifically, is a judicially originalist senator or representative bound by the meaning of "high crimes and misdemeanors" at the founding when voting on impeachment? At first blush, it seems that, on this view, Congress must be bound. Without attention to history, it can be said, the standard for impeachment becomes indeterminate. A President can be impeached for any reason, throwing the document's integrity into question. Just as we should fear the judge who finds an ahistorical right to abortion in the Constitution's penumbra in order to secure abortion rights as a matter of social policy, we should fear a congresswoman who finds an ahistorical reason to impeach a President because she does not like the President's particular policies. ${ }^{13}$

There is no doubt that this line of argument has force, but it does not succeed in defending interpretive symmetry because of a key difference between judges and legislators. Unlike judges, members of Congress are accountable for their constitutional judgments. They are up for re-election every two or six years ${ }^{14}$ and can be voted out of office if their constituents take issue with their reading of the phrase "high crimes and misdemeanors." The ability of members

11. Robert H. Bork, THE TEMPTING OF AMERICA 3-5 (1990).

12. As stated at the outset of this essay, I believe that as a textual matter Congress is required to make constitutional judgments. This position is shared by a variety of commentators. See, e.g., Paul Brest, The Conscientious Legislator's Guide to Constitutional Interpretation, 27 STAN. L. REV. 585, 587 (1975) (noting that "some provisions of the Constitution are explicitly addressed to legislators," including the Ex Post Facto Clause and the First Amendment).

Historically, this matter appears settled. To take one example, the Annals of the First Congress in 1789 reveal an extensive debate over the President's removal power in the Constitution. Some Congressmen believed that the Senate had to approve presidential removals. Some believed that impeachment was the proper remedy for the Senate to use for removal of executive officers, others believed that the Senate could use whatever mechanism it so wished. Still others believed that the removal power was committed to the President alone. Did Congress believe that this was a matter only for the courts to decide? The answer was, according to Madison, a resounding "no." He rejected the argument that "the legislature itself has no right to expound the Constitution; that wherever its meaning is doubtful, you must leave it to take its course, until the Judiciary is called upon to declare its meaning." 1 ANNALS OF CONG. 500 (J. Gales ed., 1789). Instead, he believed that it was Congress's

duty, so far as it depends upon us, to take care that the powers of the Constitution be preserved entire to every department of Government .... But I beg to know, upon what principles it can be contended, that any one department draws from the Constitution greater powers than another, in marking out the limits of the powers of the several departments? The Constitution is the charter of the people to the Government; it specifies certain great powers as absolutely granted, and marks out the departments to exercise them. If the Constitutional boundary of either be brought into question, I do not see that any one of these independent departments has more right than another to declare their sentiments on that point. Id.

13. See SCALIA, supra note 10, at 44 ("[T] he proponents of The Living Constitution [do not] follow the desires of the American people in determining how the Constitution should evolve. They follow nothing so precise; indeed, as a group they follow nothing at all.").

14. See U.S. CONST. art. I., $\S \S 2,3$. 
of Congress to impose their own preferences on the Constitution through interpretation is therefore tempered by their popular accountability. Note how this constitutional structure is very different from that governing federal judges, who have little or no accountability for their individual votes in cases, and who are protected from the ravages of ordinary politics through life tenure and salary guarantees.

An originalist could respond, however, that even if the individual members of Congress cannot impose their own will due to the accountability anchor, they certainly can pervert the meaning of the document by doing their constituents' bidding, instead of the bidding of the Founders. Consider the potential consequences of the House Managers' argument during the Impeachment Trial of President Johnson:

It is said if the impeachable crimes are not defined by law the power of impeachment will be undefined and dangerous. The power to determine impeachable crimes by the Senate is no more undefined than the power of the common law courts to determine common-law crimes. Impeachment is regulated by principles as well defined and permanently settled as the fundamental and eternal doctrines of right, reason, and justice pervading the parliamentary jurisprudence of civilized nations, and, like the common law, it has emerged from primeval errors and adapted itself to an advanced civilization.

We should all fear amorphous standards like the House Managers' that allow a President to be impeached for almost any reason at all. From this perspective, it can be said that "high crimes and misdemeanors" should have a fixed meaning, and that members of Congress should not simply vote on the basis of what their contemporary left- or right-wing voting districts might think. Here again, however, the answer is not clear.

Part of the reason that this simple and somewhat persuasive answer is still not wholly correct is that it may be impossible to devise a system that relies exclusively on the Founders' will. Naturally, as a matter of constitutional governance, it would seem simpler to have a world in which all the standards were laid down clearly ahead of time, so that we would know whether or not impeachment is a proper remedy when a President

(1) (a) lies, or

(b) obfuscates

(2) (a) to the American people, or

(b) to a court in

— direct testimony or

- a deposition

(c) to a friend or aide, or

(d) to an aide

15. Brief of the Authorities Upon the Law of Impeachable Crimes and Misdemeanors, prepared by House Manager William Lawrence, ConG. GloBE, 40th Cong., 2d Sess. app. 45 n.* (1868). 
(e) to a Head of State

(3) about a matter that is
(a) material, or
(b) nonmaterial

(4) in a
(a) civil case, or
(b) criminal case

(5) that is

(a) dismissed, or

(b) not dismissed

(6) on a matter of
(a) sexual privacy, or
(b) concerning foreign affairs
(c) concerning something else.

Simply to chart this out, of course, is to reveal the impossibility of the task-and keep in mind that this chart encompasses only lying and perjury and not the many other activities that could conceivably give rise to an impeachment. Clear standards are impossible; the factual permutations are too many, and the ability of language to capture them is limited. ${ }^{16}$ This tension between a vague rule and concrete applications is part of what gives rise to the judicial function in general. Yet when Congress sits as a court of impeachment, there are many circumstances when it is required to make similar determinations. ${ }^{17}$

The difficulty is that, however similar their interpretive task may be, members of Congress are not judges. They have political agendas, aspirations, and ideas. It would be ludicrous to think that these could all be put to one side in a debate over a question such as whether to impeach a President. To the contrary, placing the matter squarely before politicians highlights its political aspect as a courtroom duel where politics plays as important a role as morality, where polls matter more than the purity of the process. As Alexander Hamilton put it in The Federalist, impeachments will

seldom fail to agitate the passions of the whole community, and to divide it into parties more or less friendly or inimical to the accused. In many cases it will connect itself with the pre-existing factions, and will enlist all their animosities, partialities, influ-

16. Consider Chief Justice Marshall's explanation of this point:

A constitution, to contain an accurate detail of all the subdivisions of which its great powers will admit, and of all the means by which they may be carried into execution, would partake of the prolixity of a legal code, and could scarcely be embraced by the human mind. It would probably never be understood by the public. Its nature, therefore, requires, that only its great outlines should be marked, its important objects designated, and the minor ingredients which compose those objects be deduced from the nature of the objects themselves.

McCulloch v. Maryland, 17 U.S. 316, 407 (1819).

17. The Constitution gives the Senate the "sole" power to "try" impeachments and states the "Trial of all Crimes, except in Cases of Impeachment; shall be by Jury." U.S. CONST. art I, § 3, cl. 6, art. III, $\S 2$, cl. 3 . 
ence, and interest on one side or on the other; and in such cases there will always be the greatest danger that the decision will be regulated more by the comparative strength of parties, than by the real demonstrations of innocence or guilt. ${ }^{18}$

Hamilton believed that the leaders of the impeachment "can hardly be expected to possess the requisite neutrality toward those whose conduct may be the subject of scrutiny." "19 But the Framers "thought the Senate the most fit depositary of this important trust." ${ }^{20}$ After all, impeachment is "designed as a method of NATIONAL INQUEST into the conduct of public men." properly be the inquisitors for the nation as the representatives of the nation themselves?"22 Politics is inevitable in these high-stakes impeachment debates.

And this is how it should be. There is an evil greater than that produced by an indeterminacy over the meaning of "high crimes and misdemeanors"-namely, the hiding of political motivations through constitutional argument. When politicians are able to argue that the Constitution "compelled" them to impeach (or not to impeach), to remove (or not to remove), they hide their ordinary political aspirations. Appeals to history in this context can be dangerous and counterproductive because they may mask the role politics plays in the process, and thereby interfere with political accountability.

It is, of course, very difficult to make an argument that the text, history, and structure would ever compel an impeachment. A Republican who adhered to such a position in the Clinton impeachment risked constitutional ridicule: A senator should always have room to examine the seriousness of the offense, to assess a President's fitness for office, and to grant mercy if appropriate. But what about the Democrats, who claimed that the Constitution absolutely prevented Clinton from being impeached? Were they guilty of obfuscation too?

\footnotetext{
18. The Federalist No. 65, at 439-40 (Alexander Hamilton).

19. Id. at 440 .

20. $I d$.

21. Id.

22. Id. Hamilton continued:
}

Where else than in the Senate could have been found a tribunal sufficiently dignified, or sufficiently independent? What other body would be likely to feel CONFIDENCE ENOUGH IN ITS OWN SITUATION, to preserve, unawed and uninfluenced, the necessary impartiality between an INDIVIDUAL accused, and the REPRESENTATIVES OF THE PEOPLE, HIS ACCUSERS?

Could the Supreme Court have been relied upon as answering this description? It is much to be doubted, whether the members of that tribunal would at all times be endowed with so eminent a portion of fortitude, as would be called for in the execution of so difficult a task; and it is still more to be doubted, whether they would possess the degree of credit and authority, which might, on certain occasions, be indispensable towards reconciling the people to a decision that should happen to clash with an accusation brought by their immediate representatives.

Id. Hamilton's reliance on the accountability of Congress underscores the point this section has repeatedly made: that there is a fundamental representational difference between the courts and Congress.

23. See Susan Low Bloch, Impeachment Inquiry Checklist, WASH. POST, Nov. 22, 1998, at C06 (letter); Letter from Law Professors Richard Abel et al., to U.S. House of Representatives, Nov. 9, 1998, at 4. 
Probably. In their appeals to strict construction of the text and history, the Democrats were able to paint the decision to acquit as one not of their choosing, but of the Founders'. This is not a constitutionally ludicrous position. But it imposes a cost, the deflection of responsibility. There is, in this sense, less to fear from the Republican position, which was obviously political, than there was from the Democrats, whose constitutional position was more credible, and thus more likely to detract attention from their own role in the process. My point is not to suggest that the Democrats were right or wrong in the Clinton matter. It is simply to show that the predetermination of a constitutional matter such as impeachment can impose large costs, namely, the loss of accountability. In some circumstances, that may be the Constitution's goal-the Framers did not specify impeachment for any crime, but only for activities that were analogous to "treason" and "bribery." But in the tough cases, where the text and history are not clear, arguments about their determinacy can dodge accountability.

There is a stronger need for transparency in congressional context than in matters of judicial interpretation. In the congressional arena, we expect politics is going to have a role in interpretation. ${ }^{24}$ Virtue exists in letting that role be open, unabashed, and honest. Indeed, because members of Congress are accountable in future elections to the people for their constitutional judgments, our system of government should encourage frankness and candor to let elections properly serve their accountability function. For this reason, Hamilton's suggestion to the critics who claimed that the Senate would be aristocratic and unfair in impeachments was to point out that they could always be voted out, and thus were subject to popular pressure. ${ }^{25}$

Federal judicial interpretation, on the other hand, is not as closely intertwined with politics (nor should it be). No future election exists, and judges are insulated from ordinary politics by life tenure and salary guarantees. They are primarily viewed, not as Republicans and Democrats, but as impartial members of the judiciary. Indeed, there may be institutional reasons why, even if Justices act as partisans, this partisanship should not be explicitly acknowledged to preserve the myth of impartiality and stability in the law. In short, transparency is simply not as important a value for judges, who are unelected, as it is for the elected Congress. The latter are accountable in ways that the former are not.

The contrast between electorally accountable legislators and insulated judges also implies that legislators may have room for a more expansive, less historically tethered theory of interpretation than that used by courts. Indeed, a

24. This is a theme from the Federalist Papers that continues to be emphasized even today. See, e.g., Alison Mitchell, Senate Acquits Clinton Perjury and Obstruction Charges Fail to Win Majority, N.Y. TIMES, Feb. 13, 1999, at A1.

25. See THE Federalist No. 66, at 447-48 ("But this hypothesis, such as it is, has already been refuted in the remarks applied to the duration in office prescribed for the senators. It was by them shown, as well on the credit of historical examples, as from the reason of the thing, that the most POPULAR branch of every government, partaking of the republican genius, by being generally the favorite of the people, will be as generally a full match, if not an overmatch, for every other member of the Government."). 
main worry of the originalists, that unelected judges will usurp the democratic legislature, is inapplicable on its terms to legislative constitutional interpretation. $^{26}$ Of course, this worry could be recast as one of agency costs, that members of the legislature will serve their own interests and not their constituents'. As Madison put it in The Federalist, "[m]en of factious tempers, of local prejudices, or of sinister designs, may by intrigue, by corruption or by other means, first obtain the suffrages, and then betray the interests of the people." ${ }^{27}$ But, at least comparatively, agency costs are lower with Congress, which interprets the document as a popularly accountable actor, than they are with the small and unaccountable Supreme Court. For that reason, Madison believed that the large national scope and vision of Congress would minimize the agency problem. $^{28}$

A partial caveat is necessary at this stage. Members of Congress might seek illegitimately to dress up their political views with constitutional argument. ${ }^{29}$ Such practices, often in derogation of the Oath Clause, threaten democratic functioning, insofar as they permit members of Congress to blame their impeachment votes on a particular view of the Constitution. I am assuming, however, that at times, Congress will legitimately interpret the Constitution, and the question posed is what interpretive philosophy should guide their task. Government actors, whether in the legislature or the judiciary, will always be able to abuse a theory to achieve nefarious ends. If we are worried about legislators hiding their policy views behind constitutional rhetoric, this fear can counsel for, not against, nonoriginalist constitutional interpretation by the legislature. ${ }^{30}$

All of this suggests that Congress should not be bound by originalism in the impeachment context. Whatever one's philosophy of judicial interpretation,

26. See Michael W. McConnell, Institutions and Interpretation: A Critique of City of Boerne v. Flores, 111 HARV. L. REV. 153, 189 (1997).

27. Federalist 10 (Madison), in The Federalist PAPers 62 (Jacob E. Cooke ed., 1961).

28. See id. at 62-63 (explaining that agency costs will be minimized due to "the greater number of citizens and extent of territory" as well as the fact that "each Representative will be chosen by a greater number of citizens"). The risk of self-dealing is not, however, eliminated. Congress could use impeachment to undermine a democratically elected President, and that President may have a claim to represent a majority of the nation's people in a way that a bare congressional majority may not. Because of district-by-district voting and other features, a Democrat can be elected President even when Congress is predominantly Republican. (The 1996 election is a good example.) Forcing a President to garner the approval of not just the people in an election, but also a majority of Congress, could do serious violence to the structure of government and undermine the popular mandate given to the President. This may be one reason why the Framers insisted on a 2/3 vote for conviction in the Senate. See supra note 5.

29. See Larry Alexander \& Frederick Schauer, On Extrajudicial Constitutional Interpretation, 110 HARV. L. REV. 1359, 1368 (1997) ("[C]ongress has its own views about constitutional interpretation, views that conveniently produce outcomes routinely congruent with Congress's own policy views.").

30. See supra text accompanying note 23 . There may be other circumstances, largely outside of impeachment, in which nonoriginalism might give members of Congress more room to hide their policy positions than would originalism, simply by dint of the greater malleability of nonhistorical argument. In those situations, there may be a stronger argument to require originalism in Congress. This possibility again underscores the point that the reasons in favor of a particular theory of interpretation may differ with respect to the courts and Congress. Here, the reason to favor originalism in Congress is grounded in preserving the integrity of a future election and enhancing political accountability-values that do not exist in the judicial context. 
there were solid reasons to break away from the 1787 view of "high crimes and misdemeanors." An interpretation focused on that time period would be anachronistic, and it would be difficult to explain its relevance to the American public. The grand words used in the Constitution did not, as Marshall said, "partake of the prolixity of a legal code," judgment. The fear that unelected and unaccountable jurists will mask their political views under the guise of constitutional interpretation is not as applicable to Congress. To the contrary, it is expected that politics will play a role in impeachment. Forcing members of Congress into a box where they must pick between Jefferson's and Hamilton's views of "high crimes" hides these expected and natural political motivations. Thus, there is a strong case to be made for legislative nonoriginalism in the impeachment context.

What works in the impeachment context, however, might not fully work for other constitutional clauses. It may be proper for other clauses to have a fixed, nonevolving meaning. To the extent such clauses exist, the analysis above will not be applicable. For the remaining clauses, however, there, nevertheless, remains the possibility that there should be a difference in the degrees to which legislative and judicial interpretation is tethered to originalism. There are reasons to favor legislative nonoriginalism and judicial originalism-reasons that stem from the legislature's accountability and the need for subterranean constitutional change through legislative, not judicial, interpretation. As I will argue in a forthcoming article, legislative nonoriginalism provides an interesting way for resolving one of the most perplexing issues in constitutional interpretation: the role of abstraction. ${ }^{32}$ For now, however, it is best to keep our focus on impeachment.

\section{B. Protection-of-Minorities School}

A separate school of constitutional thought contends that the Constitution exists to protect the interests of the minority against the excesses of the majority. This Protection-of-Minorities School believes that provisions in the Bill of Rights, as well as the structural safeguards in the Constitution, reflect a distrust of majorities, and that there should be some matters that are presumptively off limits to the legislature and the people whom they represent. ${ }^{33}$ Under this theory, Article III protections exist to insulate judges from the ordinary political process and to put judges in the position of safeguarding minority interests. Consequently, academics have argued that protection of minority interests demands that courts take an active role in constitutional interpretation, a role not

31. McCulloch v. Maryland, 17 U.S. 316, 407 (1819).

32. See Katyal, supra note 6; see also Bruce Ackerman, Liberating Abstraction, 59 U. CHI. L. REV. 317, 347 (1993); Paul Brest, The Fundamental Rights Controversy: The Essential Contradictions of Normative Constitutional Scholarship, 90 YALE L.J. 1063, 1085 (1981) ("The indeterminancy and manipulability of levels of generality is closely related, if not ultimately identical, to the arbitrariness inherent in accommodating fundamental rights with competing government interests.").

33. See, e.g., Erwin Chemerinksy, Foreword: The Vanishing Constitution, 103 HARV. L. REV. 43, 85-88 (1989). 
always constrained by the original understanding of the document. ${ }^{34}$ Because legislatures are to be distrusted, the theory contends, unelected judges stand in the best position to defend minorities.

Again, the point is not to quarrel with the theory, but simply to suggest that it can yield dramatically different outcomes when applied to legislative and judicial interpretations. To illustrate the point, think of the following example: President Smith in 2006 decides to come out of the closet and reveal herself to be gay after she is caught with another woman in a Georgia hotel room. Congress immediately begins impeachment proceedings, arguing that violation of Georgia's sodomy statute is a "high crime and misdemeanor." ${ }^{35}$ At the same time, Smith is convicted in state court for violating the statute. ${ }^{36}$ Arguing the right to privacy, Smith appeals the conviction all the way to the United States Supreme Court. How should the Supreme Court rule?

There are those who would argue that the Justices should rule for Smith. Consider, for example, Justice Blackmun's argument in the dissent in Bowers $v$. Hardwick:

I cannot agree that either the length of time a majority has held its convictions or the passions with which it defends them can withdraw legislation from this Court's scrutiny. As Justice Jackson wrote so eloquently for the Court in West Virginia Board of Education v. Barnette, "we apply the limitations of the Constitution with no fear that freedom to be intellectually and spiritually diverse or even contrary will disintegrate the social organization.... [F]reedom to differ is not limited to things that do not matter much. That would be a mere shadow of freedom. The test of its substance is the right to differ as to things that touch the heart of the existing order." It is precisely because the issue raised by this case touches the heart of what makes individuals what they are that we should be especially sensitive to the rights of those whose choices upset the majority.

This argument tracks the assumptions of the Protection-of-Minorities School outlined above. In particular, note how Justice Blackmun is arguing that the Court should scrutinize-be "especially sensitive" to-a statute's invasion of that which makes "individuals what they are." This leads Justice Blackmun to adopt a rather broad interpretation of the Fourth Amendment, and other rights, to formulate a principle that prevents prosecution under the Georgia law. ${ }^{38}$ In the judicial context, therefore, Blackmun and the Protection-of-Minorities School seek an expansive power of interpretation for judges to protect them against abuses by the polity.

\footnotetext{
34. See id. at $98-103$.

35. The Georgia statute provides:

(a) A person commits the offense of sodomy when he or she performs or submits to any sex-

ual act involving the sex organs of one person and the mouth or anus of another....

(b) A person convicted of the offense of sodomy shall be punished by imprisonment for not less than one nor more than 20 years.
}

GA. CODE ANN. § 16-6-2 (1999).

36. For purposes of the hypothetical, one can leave aside the issue of whether a sitting President can be indicted.

37. 478 U.S. 178, 211 (1986) (Blackmun, J., dissenting) (citations omitted).

38. See id. at 206-12. 
In the impeachment context, the question is not whether President Smith is guilty of a crime, but whether she has committed a "high crime and misdemeanor." One hopes that, in interpreting this phrase, Congress would not confuse prejudice with principle, voting against Smith due to her orientation. But the distrust of the majority implicit in the Protection-of-Minorities School belies that hope. Instead, the School fears vesting Congress with dramatic and openended power. The School believes that courts sit to curb Congress's unchecked power. In the impeachment context, however, there is no judicial remedy and no right of appeal. In addition, the constraint discussed in the preceding section of this essay, accountability, is not satisfying because accountability to the majority is not much of a comfort at all.

From this perspective, the School would argue that not only is it conceivable, it is a good thing to limit the activities that can serve as the basis for impeachment. Because open-ended grants of power to majorities are to be feared, the style of interpretation must constrain the legislature. The School would consider the Founders' view of impeachment as reserved for political offenses, of crimes against the state; this limitation serves to constrain the politicians' prejudice in their interpretation of the Constitution. Broader views of what constitutes impeachable offenses, such as the ones the Republicans trotted out at various times during the Clinton impeachment, like abuse of trust or bringing ill repute on the presidency, would be deemed susceptible to prejudice. History acts to brake the exercise of such prejudice because one fears the manipulation of noninterpretivist methodology by an unsympathetic and even hostile Congress. In such a circumstance, it is precisely because the legislature is accountable that one would insist on its adherence to originalism.

In response, a nonoriginalist could say, since the privacy principle can be divined from nonoriginalism in the judicial context, the legislature should be given the tools of nonoriginalism to permit them to mount a privacy defense as well. In short, what works for the Bowers dissenters should work for Congress too. However appealing that argument may be, it is belied by the central assumption of the Protection-of-Minorities School-that the legislature is not to be trusted in expanding minority rights. ${ }^{39}$ The best that can be hoped, under this assumption, is that the legislature has strict guidelines on what it can do, so that it cannot interpret vagueness in the Constitution against a minority. The more interpretive tools Congress has at its disposal to manipulate the Constitution, the argument goes, the greater Congress's power to oppress minorities.

Concerns that Congress is prone to interpret the Constitution to disadvantage minorities may exist in areas outside of impeachment. Congress might adopt a narrow view of the Fifteenth Amendment in order to claim that the Voting Rights Act is unconstitutional. Congress might interpret section Five of the Fourteenth Amendment narrowly so it can refuse to pass legislation outlawing hate crimes. In such circumstances, one might want to insist upon a nar-

39. See Chemerinksy, supra note 33 , at $85-88$. 
row range of interpretive styles in order to constrain the tools the legislature has for making such arguments. ${ }^{40}$ This is the logical outgrowth of the central tenet of the Protection-of-Minorities School, that legislatures are not to be trusted, and that courts, due to their insulation, should be given greater leeway in interpreting the Constitution.

The point that interpretive symmetry need not exist for originalists and nonoriginalists has applicability beyond the context of where one stands on the question of original intent. I do not want to sketch out all of the different implications in this short symposium contribution. However, I do want to illustrate how divergences may arise with two additional examples: the role of precedent and the role of morality in constitutional interpretation. Again, the Clinton impeachment provides a helpful lens to view these matters.

III

\section{THE ROLE OF PRECEDENT}

At issue in the Clinton impeachment was not simply the role of history, but also the role of precedent. In interpreting the meaning of "high crimes and misdemeanors," what was Congress to make of the other impeachments over time, such as those of Justice Chase and President Johnson? Did these precedents require Congress either to impeach or not to impeach President Clinton? Furthermore, was the vote against Clinton's impeachment and removal binding for future similar instances?

Both Democrats and Republicans made two types of arguments from precedent-backward-looking and forward-looking. Democrats looked back to argue that the precedent of Chase, Johnson, and Nixon militated strongly against impeaching President Clinton. ${ }^{41}$ They looked forward to contend that a vote to impeach would set a future precedent that a President could be removed for virtually any reason at all, thus undermining popular rule. ${ }^{42}$ The Republicans, on the other hand, looked back to argue that the rules laid down in the Chase and Johnson impeachments supported Clinton's impeachment. ${ }^{43}$ They looked forward to contend that a refusal to impeach and remove President Clinton would set a dangerous precedent for future Presidents. Consider House Manager McCollum's impassioned argument:

40. Of course, there may be circumstances in which originalism will yield results that are harmful to minorities. In such cases, a natural impulse exists to ask whether nonoriginalism in the legislature might be more helpful in protecting such individuals. However, if one begins with the premise of the School, that the legislature is not to be trusted, then arming Congress with open-ended tools should not be expected to produce beneficial results. Instead, the task should focus on damage control-on constraining the discretion of Congress as much as possible. To the extent that other constitutional methodologies constrain congressional discretion in a given case, the School would be expected to endorse them.

41. See, e.g., 145 CONG. REC. S59-02, S195-97 (1999) ("Past precedents confirm that allegations of dishonesty do not alone state impeachable offenses.").

42. See id. at S196 ("To make impeachable offenses of these allegations would forever lower the bar in a way inimical to the Presidency and to our government of separated powers.").

43. See 145 CONG. REC. S59-02, S73-77, S216-20, S1792 (1999). 
What are the consequences of failing to remove this President from office if you believe he committed the crimes of perjury and obstruction of justice? ... First, at the very least, you will leave a precedent of doubt as to whether perjury and obstruction of justice are high crimes and misdemeanors in impeaching the President. In fact, your vote to acquit under these circumstances may well mean that no President in the future will ever be impeached or removed for perjury or obstruction of justice. Is that the record that you want?

Second, you will be establishing the precedent that the standard for impeachment and removal of a President is different from that of impeaching or removing a judge or any other official .... So while the Constitution on its face does not make a distinction for removing a President or removing a judge, if you vote to acquit, believing that the President committed perjury and obstruction of justice, for all times you are going to set a precedent that there is such a distinction.

Third, if you believe the President committed the crimes of perjury and obstruction of justice and that they are high crimes and misdemeanors, but you do not believe a President should be removed when economic times are good and it is strongly against the popular will to do so, by voting to acquit you will be setting a precedent for future impeachment trials. Can you imagine how damaging that could be to our constitutional form of government, to set the precedent that no President will be removed from office for high crimes and misdemeanors unless the polls show that the public wants that to happen? Would our Founding Fathers have ever envisioned that? Of course not. Our Constitution was structured to avoid this very situation.

Are you going to put on the record books the precedent that all who serve under the President and whom he has appointed will be held to a higher standard than the President? What legacy to history is this? What mischief have you wrought to our Constitution, to our system of government, to the values and principles cherished by future generations of Americans? ${ }^{44}$

But is this so obvious? Why should Congress be bound by its previous determinations? As Professor Monaghan reminds us, stare decisis is important in courts because of two central features: stability and legitimation of judicial review. ${ }^{45}$ The argument based on stability is that adherence to stare decisis prevents issues that are central to our society from being reopened in the courts. ${ }^{46}$ The argument based on judicial review is that "[e]ven when the prior judicial resolution seems plainly wrong to a majority of the present Court, adherence to precedent can contribute to the important notion that the law is impersonal in

44. 145 CONG. REC. S1337-02, S1355.

45. See Henry P. Monaghan, Stare Decisis and Constitutional Adjudication, 88 ColuM. L. REV. 723, 748-56 (1988). There are many other arguments that counsel adherence to precedent besides those advanced by Monaghan. For a discussion of these other arguments and their applicability to impeachment, see Katyal, supra note 6.

46. See Monaghan, supra note 45, at 750. Justice Scalia also defends the use of precedent in constitutional adjudication as necessary for stability in the rule of law. See SCALIA, supra note 10, at 138-40; see also BMW Inc. v. Gore, 517 US 559, 597 (1996) (Scalia J., dissenting); Planned Parenthood v. Casey, 505 U.S. 833, 993 (1992) (Scalia, J., concurring in part and dissenting in part); Walton v. Arizona, 497 U.S. 639, 672-73 (1990) (Scalia, J., concurring in part and concurring in judgment). But this argument will not, as its supporters recognize, support adherence to stare decisis in all circumstances. Rather, the stability argument is weighty only when the issues are central to critical shared expectations and values. See Monaghan, supra note 45, at 751-53. This is the logic of the Casey plurality as well. See Casey, 505 U.S. at 866-69 (plurality opinion). 
character, that the Court believes itself to be following a 'law which binds [it] as well as the litigants." ${ }^{47}$

Neither of these arguments is necessarily compelling in the legislative context. The first argument, based on stability, is rooted in the limited nature of Article III courts, and the judiciary's ability to restrict and limit its agenda through use of the passive virtues and other techniques. But Congress is not a court of limited jurisdiction. Rather, it is the Constitution's hope that Congress, as the representative of the people, will engage in a multiplicity of issues in order to bring the voice of the people to bear on the important questions of the day. Such engagement might not be appropriate for the judiciary, which is a countermajoritarian institution. But our constitutional system should and does encourage the testing of ideals in the political process. Appeals to precedent, just like appeals to history, may mask political aspirations and diffuse responsibility. ${ }^{48}$

The impeachment context is the closest analogy to the Article III court of limited jurisdiction. Congress performs a very narrow function, and the concerns about stability are at their height when one is considering removing a sitting President. Such concerns are exacerbated when the legislature does not have a popular mandate. Suppose that, as many believed, Congress in the Clinton impeachment was not representing the people. ${ }^{49}$ The popular President was being dragged through the mud, not because this was what the American people wanted, but because this is what the Republican Party wanted. In such a circumstance, if Congress does not have a claim to speak for the people, adherence to longstanding precedent may be justified. The same countermajoritarian concerns at issue with judicial interpretation (as per Monaghan) or with executive interpretation (as per Madison) might counsel adherence to stare decisis in the legislative context. Doing so reflects the view that even if no one entity can legitimately speak for the people at any given time, the cumulative weight of successive speakers is imbued with as democratic a character as possible.

We might question whether this rationale, based on democratic representation, justifies adherence to stare decisis by judges, even if it does account for legislative precedent. Unlike legislative precedent, which has a representational quality to it, judicial precedent reflects the views of a few isolated judges at a given point in time. Consider the words of Representative John C. Calhoun defending an internal improvement bill. Calhoun pointed to earlier uses of Congress's spending power, and rejected the view that his interpretation replaced a Constitution of "positive and written principles" with one "founded on precedents." Calhoun "introduced the uniform sense of Congress and the country (for they had not been objected to) as to our powers; and surely, said he, they furnished better evidence of the true interpretation of the Constitution than the

47. See Monaghan, supra note 45 , at $752-53$.

48. See supra text accompanying notes 23-24 (discussing how, in impeachment context, historical arguments can undermine accountability).

49. See e.g., John J. Miller, No Need to Hide, N.Y. Times, Feb. 18, 1999, at A21. 
most refined and subtle arguments." ${ }^{50}$ The insight here is that longstanding legislative determinations might have a better claim to speak for the people's constitutional determination than do judicial ones, and should, therefore, be entitled to greater weight.

The second argument for adherence to stare decisis by the courts, legitimation of judicial review, flounders on its own terms in the legislative context. There is no anomalous institution of "legislative review" that requires sensitivity to counter-democratic concerns. However, implicit in this second argument is a claim about fairness: Like cases should be treated alike. ${ }^{51}$ This point may be applicable in some circumstances, such as when the Senate is sitting as a court of impeachment. Without an impartial proceeding, the integrity of the

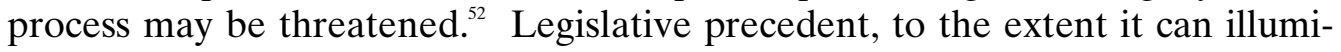
nate interpretive questions by appealing to a past with different actors, may help reduce the risk of political bias.

The impartiality point can be understood by returning to James Madisonalbeit a different set of Madison's words. Toward the end of his life, Madison highlighted three features as important to deciding what governs interpretation of the Constitution:

(1) The evils \& defects for curing which the Constitution was called for \& introduced.

(2) The comments prevailing at the time it was adopted.

(3) The early, deliberate \& continued practice under the Constitution, as preferable to constructions adapted on the spur of occasions, and subject to the vicissitudes of party or personal ascendencies.

Madison's last point emphasizes Congress's role in interpretation, which is not to give effect to party politics in its constitutional interpretation, but rather to reflect seriously upon settled and intentional constructions of the document. His words can be read to suggest an argument against the use of legislative precedent in the impeachment context. After all, it is quite clear that an impeachment vote could be subject to the "vicissitudes of party or personal ascendencies." In such a circumstance, the Madisonian position would counsel disregarding such precedent.

Or would it? This is another circumstance in which discussing legislative constitutional interpretation highlights lessons of more general applicability. After all, Madison is only discussing the ex post use of a precedent that is motivated by party politics. Consider, however, whether, ex ante, Congress should

50. John C. Calhoun, 1 The Papers of John C. Calhoun 398, 404 (Robert L. Meriwether ed., 1959).

51. See Frederick Schauer, Precedent, 39 Stan. L. REV. 571, 595-97 (1987).

52. See U.S. CONST. art. I, § 3. In his opening remarks in the defense of President Johnson before the Senate, Benjamin Curtis argued that "[h]ere party spirit, political schemes, foregone conclusions, outrageous biases can have no fit operation. The Constitution requires that here should be a 'trial,' and as in that trial the oath which each one of you has taken is to administer 'impartial justice according to the Constitution and the laws." CONG. GLOBE, 40th Cong., 2d Sess. app. 123 (1868).

53. 9 JAMES MADisOn, THE Writings OF JAMES MADISON 370, 372 (Galliard Hunt ed., 1910). 
create an institutional rule or practice in favor of adherence to legislative precedent. Ironically, the very fact that legislative precedent can be personal and political might militate for, not against, the respect for legislative precedent.

The reason goes back to the distinction between backward-looking and forward-looking arguments from precedent. A forward-looking doctrine of stare decisis for the legislature can, in certain contexts, actually reduce partisanship in constitutional adjudication. This is easiest to see with the impeachment context. Republicans and Democrats have no idea who will be President in 2001, or in 2011; they are voting behind a veil of ignorance. If the position they argue for today is binding on future Congresses, Congress may be less likely to act out of partisan interests. In such a circumstance, a strong stare decisis rule will act as an encouragement to sobriety and to evenhandedness. Therefore, it might be wise to adopt a rule that is the opposite of the one Madison wanted. It is precisely in situations where partisanship is likely that the rule of stare decisis should be adopted; doing so will constrain party politics in the case at hand.

A pair of final arguments favoring adherence to precedent in the judicial context deserve mention. Fred Schauer has argued that adherence to precedent enhances the predictability of law, and allows individuals to plan their affairs accordingly. ${ }^{54}$ Even if the rule is suboptimal, Schauer notes, stare decisis might be justified because predictability is a more important value. Second, borrowing from Edmund Burke, Tony Kronman has argued that respect for precedent is constitutive of who we are. ${ }^{55}$ The past should be respected for its own sake, for fidelity to tradition is part of what sets humans apart from other beings as cultural entities.

The first of these arguments applies in two senses to impeachment. First, clear standards for what constitutes high crimes and misdemeanors allow Presidents to conduct their business without fear that their activities will one day serve as the basis for an impeachment. In this context, the idea is the same as the one expressed in official immunity cases such as Nixon v. Fitzgerald ${ }^{56}$ that the President needs a zone of freedom in which to operate, or his official activities will be chilled. Second, the public needs a predictable definition of high crimes and misdemeanors. Informing the electorate about the range of behavior that is impeachable before an election may influence the type of candidate for whom they vote. Predictable definitions of what constitutes a high crime will also minimize the temptation to make-up constitutional standards to fit a given situation.

On the other hand, just as with the text, we may question whether it is even possible to ever come up with a sufficient set of precedents that will encompass every situation of what is a high crime or misdemeanor. The range of possibilities is too vast, the potential offenses too many. As House Manager Benjamin Butler put it during the impeachment trial of President Johnson, it is not possi-

\footnotetext{
54. Schauer, supra note 51, at 597-98.

55. See Anthony T. Kronman, Precendent and Tradition, 99 YALE L.J. 1029, 1066 (1990).

56. 457 U.S. 731 (1982).
} 
ble to anticipate the "infinite gradations of human wrong and sin by which the liberties of the people and the safety of a nation may be endangered." ${ }^{157}$ So predictability may be elusive. What is more, predictability may be dangerous-for what counts as acceptable behavior in one generation may not be so in the next. Just think of slavery. Nevertheless, the point has some force in suggesting that the type or range of behavior that is impeachable ought to be enumerated to the extent it is possible-in the same way that abstract ideas like "due process" are given content by government actors today.

The predictability arguments have some force in the non-impeachment context as well. Individuals and corporations need to structure their affairs against a backdrop of what the government can and cannot do to (and for) them. The Takings Clause, for example, is a powerful inducement for investment and capital formation. The First Amendment helps ensure that people will become journalists. Judicial precedents have obvious force in securing these rights, but adherence to legislative precedent may also help contribute to stability in both the corporate and individual sectors.

Kronman's argument for precedent applies equally to the judicial and legislative sectors. When Congress takes up the question of what is a high crime and misdemeanor, it does so within a cultural-legal tradition. To break away and ignore what has come before slights our commitment to this tradition, and places us in a world divorced from context. We must act with "infinite caution" before venturing to "pull[] down an edifice which has answered in any tolerable degree for ages the common purposes of society." 58 For Congress to approach these questions with the arrogance of a philosopher is not only foolish, it ignores our identity as humans. What's more, I suspect, it also ignores the values of our Constitution, which were not meant to be cast aside and picked up again like the latest fashion in trousers, but were intended to endure.

Two final differences should be mentioned in determining whether interpretive asymmetry is justified with respect to legislative and judicial precedent. First, unlike congressional determinations, court decisions are presumed to be somber and deliberative, reflecting the best thinking of the Court at the time. Congress, by contrast, acts hastily and without information at times, so that its determinations might be entitled to less weight. (Madison himself believed statutes passed without this sobriety should not be considered binding: These "midnight precedents ... ought to have little weight in any case." ${ }^{, 59}$ ) For this

57. Cong. Globe, 40th Cong., 2d Sess. 29 (1868).

58. Kronman, supra note 55, at 1056 (quoting Edmund Burke, REFLECTIONS ON THE REVOLUTION IN FRANCE 152 (C. O'Brien rev. ed. 1969) (1790)).

59. Letter from James Madison to Judge Spencer Roane (May 6, 1821), in MADISON, supra note 53, at 55, 61 ("In resorting to legal precedents as sanctions to power, the distinctions should ever be strictly attended to, between such as take place under transitory impressions, or without full examination and deliberation, and such as pass with solemnities and repetitions sufficient to imply a concurrence of the judgment \& will of those, who having granted the power, have the ultimate right to explain the grant. Altho' I cannot join in the protest of some against the validity of all precedents, however uniform \& multiplied, in expounding the Constitution, yet I am persuaded that Legislative precedents 
reason, many at the founding of the Constitution believed that legislative action did not immediately become "part of the [constitutional] instrument." Rather, legislative precedent had to be approved by "the uniform acquiescence of the nation." ${ }^{\circ 1}$ Second, because congressional determinations might be found in a variety of different places, including many different senators' and representatives' speeches, it is more difficult to glean a constitutional judgment from a congressional determination than it is from reading the United States Reports. Such a difference may counsel in favor of greater deference to judicial than legislative precedent. ${ }^{62}$

In sum, several arguments tend to suggest that interpretive asymmetry should exist insofar as the legislative and judicial branches defer to their own precedents. Many reasons that undergird judicial respect for stare decisis, such as the limited nature of Article III courts, do not apply with equal force to the legislative context. Nevertheless, impartiality concerns do come into play when Congress sits as a court of impeachment. The potential for politicization may be an argument in favor of legislative adherence to precedent. Similarly, the democratic nature of longstanding legislative precedent suggests that Congress should give greater weight to precedent than the Court should. Such differences need to be considered when evaluating whether the courts and Congress should be equally respectful of their precedents.

IV

\section{THE USE OF MORAL PHILOSOPHY}

A popular proposal argues that judges should look to moral philosophy in interpreting the Constitution. Ronald Dworkin, the primary exponent of this view, contends that judges must decide cases on the basis of how the "abstract moral principles" of the Constitution are "best understood." ${ }^{3}$ The "moral reading" means that judges should "find the best conception of constitutional

are frequently of a character entitled to little respect, and that those of Congress are sometimes liable to peculiar distrust.").

60. Turpin v. Locket, 10 Va. (6 Call) 113, 185 (1804) (Lyons, P., \& Carrington, JJ.).

61. 32 AnNAls Of CONG. 1325 (1818) (speech of Henry St. G. Tucker).

62. Consider Senator Henry Clay's aforementioned views on the Bank of the United States. HENRY ClAY, Speech on the Bill to Recharter the Bank of the United States (Feb. 15, 1811), in 2 Henry Clay, THE PAPERS OF Henry Clay 537 (James F. Hopkins ed., 1961). Clay attacked reliance on legislative precedent as

fraught with the most mischievous consequences.... It will be as diffused and intangible as the pretended constitution of England. And it must be sought for in the statute book, in the fugitive journals of Congress, and in reports of the Secretary of the Treasury. What would be our condition if we were to take the interpretations given to that sacred book, which is or ought to be the criterion of our faith, for the book itself? We should find the Holy Bible buried beneath the interpretations, glosses and comments of Councils, Synods, and learned diId. vines....

63. See Ronald Dworkin, Freedom's Law: The Moral REAding of the American Constitution (1996); Ronald Dworkin, The Arduous Virtue of Fidelity: Originalism, Scalia, Tribe, and Nerve, 65 FORDHAM L. REV. 1249 (1997). 
moral principles ... that fits the broad story of America's historical record. It does not ask them to follow the whisperings of their own consciences or the traditions of their own class or sect if these cannot be seen as embedded in that record." ${ }^{64}$ When different conceptions of the constitutional principle satisfy the tests of "language, precedent, and practice," Dworkin says, "thoughtful judges must then decide on their own which conception does most credit to the nation." ${ }^{65}$

It is difficult to know exactly what such a moral claim would look like when it comes to a matter such as impeachment. Does "credit to the nation" require removal of a lying President? Does it require that he stay, given the abusive investigative techniques and possible entrapment? Hard to know. These questions typify the criticism Dworkin has received in the constitutional literature. Professor McConnell summarizes the arguments well:

$[\mathrm{T}]$ here is no reason to believe that judges are likely to be more reliable than representative bodies in discovering and enforcing natural right. Judges are grossly unrepresentative of the population. All are lawyers, most are middle-aged or older, all are upper-middle class or above, most are white males, most are secular and skeptical in their philosophical orientation, in common with the professional elite of this country. Rather than natural right, judges are more likely to impose upon us the prejudices of their class. The nature of their task makes it more attractive to seek the abstract solution than the intelligent compromise. The doctrine of precedent, so important to the court's system of institutional authority and integrity, makes correction of mistakes relatively difficult. The courts' fact-finding ability is woefully deficient. They are dependent for information and ideas upon people with an inherent professional axe to grind. They are carefully insulated from the real world. Their caseloads (especially the Supreme Court's) are overwhelming. They have little time for even the most important of cases, and it is the rare Supreme Court Justice who can keep up with more than a negligible sampling of the poetry, science, economics, literature, philosophy, theology, and history that should inform an expositor of moral reality. Their sole assistants are bright young things just out of law school. Perhaps most importantly, judges are irresponsible in the most fundamental sense: They are not accountable for the consequences of their decisions and ordinarily are not even aware of them. Power without responsibility is not a happy combination. ${ }^{66}$

Simply to list these problems is to reveal how little they have to do with legislative interpretation and the use of morality as a guide to that interpretation. Obviously, the responsibility problem is much less severe in the context of elected legislative officials. They may not be fully representative of the people, but barring the process-reinforcement exception, ${ }^{67}$ they are more representative than are the courts. Members of Congress reflect a relatively broad crosssection of American social and political life. They are (thankfully) not all law-

64. DWORKIN, FREEDOM'S LAW, supra note 63, at 11.

65. Id.

66. Michael W. McConnell, Symposium on Interpreting the Ninth Amendment: A Moral Realist Defense of Constitutional Democracy, 64 CHI.-KENT L. REV. 89, 105-06 (1988).

67. See John Hart Ely, Democracy AND Distrust (1980). This concern suggests that the use of morality may be asymmetric in cases of process failure. Congress might use arguments from morality to hurt minorities insofar as such minorities are not represented in Congress. Judges may have less of a representational skew, and therefore may be better suited to using morality as an argument in such circumstances. 
yers. They are experts at compromise and pragmatics. They have the resources of the entire federal government, including the Library of Congress, to bring to bear on any necessary factfinding missions. In short, there are crucial differences between Congress and the courts in this area, and these differences might counsel in favor of a moral reading of the Constitution by Congress.

Congress might use its considerable expertise in determining the moral pulse of the nation to illuminate constitutional questions such as the meaning of "high crimes and misdemeanors." Unlike the largely insulated courts, Congress is well suited to trying to ascertain public sentiment on particular issues. With polls, meet-and-greets, constituent outreach, and a variety of other mechanisms, Congress is relatively in touch with the American populace, and constitutional interpretation may benefit from such connections. ${ }^{68}$ Given the fact that it is one set of representatives who are being asked to remove another representative, should not the voice of the people inform whether to impeach and remove? Even as noted a constitutional scholar as Charles Black has argued that Congress cannot listen to popular views in impeachment. ${ }^{69}$ I disagree. Congress should take those views into account, particularly when the issue concerns something like whether a President is able to do his job. In so doing, Congress must also take the text, history, and structure into consideration, but it should then ask whether popular opinion bears on the question of whether or not the President committed an impeachable offense.

Other than the representational and expertise points, another persuasive argument against judges using a moral philosophy to interpret the Constitution is that its use would preempt a popular debate on those moral values. "If the quest for justice is taken out of the political arena and moved into the branch of government uniquely insulated from popular participation, one of the great functions of republicanism will be lost."70 Note how legislative interpretation could facilitate that national conversation: People can deliberate about the important constitutional questions of the day, using morality as one tool to inform that interpretation. In other words, a main vice of judicial use of moral philosophy is converted into a virtue when it is legislators who are embracing the moral Constitution.

On the other hand, there are instances in which we might want to have the courts, not the Congress, embrace a moral reading of the Constitution. In general, these exceptions occur outside of the impeachment context, and will be discussed in my forthcoming work. ${ }^{71}$ Suffice it to say that the use of morality in

68. Naturally, this argument in favor of a moral reading of the Constitution by the legislature naturally presupposes that the vague clauses in the text of the Constitution grant the interpreter the ability to make such judgments. To the extent a particular constitutional text squarely decides a matter, the moral reading of the Constitution should not be used by Congress. I do not read Dworkin to advocate anything different for the courts. See DWORKIN, FREEDOM'S LAW, supra note 63, at 8-11.

69. CHARLES BLACK, IMPEACHMENT 20 (1998) ("The taking, at intervals, of public opinion polls on guilt or innocence, should be looked on as an unspeakable indecency.").

70. See McConnell, supra note 66, at 109.

71. See Katyal, supra note 6. 
constitutional interpretation is a particularly difficult issue because of the various disagreements over the content and open-endedness of any philosophical principle. Yet these disagreements again highlight why interpretive asymmetry may be appropriate, and raise the question of whether our guiding philosophy of constitutional interpretation in the courts should govern Congress as well.

$\mathrm{V}$

\section{CONCLUSION}

The foregoing journey through the impeachment of President Clinton demonstrates that the myth of interpretive symmetry needs to be rethought. Although there are arguments for and against the use of original intent, many of those arguments depend on who is doing the interpreting. There are also arguments for and against stare decisis, but the validity of them depends on factors such as the representational quality of the interpretive body and the specific matter at hand. The use of morality similarly turns on the qualities that the particular interpreter brings to the task. Rather than resolving these questions, the goal of this essay has been simply to show that there are a range of appealing combinations that constitutionalists could profit from exploring. This is one task that constitutional scholars face in the wake of the 105th Congress's constitutional determinations that President Clinton committed a "high crime and misdemeanor" but that he should not be removed from office. 